Article

\title{
Endolysins from Antarctic Pseudomonas Display Lysozyme Activity at Low Temperature
}

\author{
Marco Orlando ${ }^{1}$, Sandra Pucciarelli ${ }^{2}$ and Marina Lotti $1, * \mathbb{C}$ \\ 1 Department of Biotechnology and Biosciences, State University of Milano Bicocca, 20126 Milano, Italy; \\ m.orlando14@campus.unimib.it \\ 2 School of Biosciences and Veterinary Medicine, University of Camerino, 62032 Camerino, Italy; \\ sandra.pucciarelli@unicam.it \\ * Correspondence: marina.lotti@unimib.it; Tel.: +39-02-64483527
}

Received: 26 October 2020; Accepted: 18 November 2020; Published: 20 November 2020

\begin{abstract}
Organisms specialized to thrive in cold environments (so-called psychrophiles) produce enzymes with the remarkable ability to catalyze chemical reactions at low temperature. Cold activity relies on adaptive changes in the proteins' sequence and structural organization that result in high conformational flexibility. As a consequence of flexibility, several such enzymes are inherently heat sensitive. Cold-active enzymes are of interest for application in a number of bioprocesses, where cold activity coupled with easy thermal inactivation can be of advantage. We describe the biochemical and functional properties of two glycosyl hydrolases (named LYS177 and LYS188) of family 19 (GH19), identified in the genome of an Antarctic marine Pseudomonas. Molecular evolutionary analysis placed them in a group of characterized GH19 endolysins active on lysozyme substrates, such as peptidoglycan. Enzyme activity peaks at about $25-35{ }^{\circ} \mathrm{C}$ and $40 \%$ residual activity is retained at $5{ }^{\circ} \mathrm{C}$. LYS177 and LYS188 are thermolabile, with Tm of 52 and $45^{\circ} \mathrm{C}$ and half-lives of 48 and $12 \mathrm{~h}$ at $37^{\circ} \mathrm{C}$, respectively. Bioinformatics analyses suggest that low heat stability may be associated to temperature-driven increases in local flexibility occurring mainly in a specific region of the polypeptide that is predicted to contain hot spots for aggregation.
\end{abstract}

Keywords: cold adaptation; cold-active enzyme; endolysin; glycoside hydrolase 19

\section{Introduction}

Adaptation to life in cold environments translates into a variety of molecular changes in the cell structures and in the features of macromolecules of the so-called psychrophilic organisms $[1,2]$. The body of information built over the years shows a large diversification in adaptation strategies that pinpoints, beside the relevance of the selective pressure exerted by temperature, also the importance of the evolutionary history organisms followed. This is clearly shown by the variety of sequences, structures, and biochemical properties of cold-active enzymes, where cold activity is defined as the ability to retain relevant residual activity up to temperatures close to $0{ }^{\circ} \mathrm{C}$. It is broadly accepted that most cold-active proteins can cope with cold temperatures since they are endowed with either high global or local flexibility of the protein chain [3,4]. Flexibility often results in the decrease of the thermal stability of the whole protein structure or, in case it is restricted to the active site region, in localized heat lability that triggers inactivation at a temperature lower than the temperature of protein unfolding $[5,6]$. A trade-off between activity in the cold and stability is reported as a feature of cold-active enzymes. Nevertheless, examples of proteins that are both cold-active and thermo-resistant are reported, suggesting that combination of only apparently contrasting properties can arise from the evolutionary pathway followed by specific sequences [7]. 
Besides the relevance of understanding the molecular and evolutionary grounds of cold adaptation, enzymes from psychrophilic organisms may find application in biocatalysis and other fields of biotechnology [8,9]. Indeed, high specific activity at low temperature is of advantage for energy saving and in processes in which heat-sensitive substrates are used and side reactions should be avoided, such as, for example, in the food industry and in fine chemistry. A further benefit of psychrophilic and heat-labile enzymes relies on the possibility to inactivate them through small temperature increases $[8,10]$.

Organisms from Antarctic seawater are investigated as sources of materials and biomolecules for application in biotechnology and health care [11-15]. In this frame, we studied Antarctic bacteria and unicellular eukaryotes sampled at Terranova Bay to obtain cold-active enzymes and antifreeze proteins [16,17]. This work focused on glycoside hydrolases of family 19 (GH19) according to the classification of CAZy, the database of carbohydrate active enzymes [18]. GH19 enzymes are endo-glycosidases and hydrolyse $\beta-1,4$ glycosidic bonds by inverting the anomeric configuration of the C1 [19]. They are classified either as endochitinases (EC: 3.2.1.14) that cleave glycosidic bonds between $\mathrm{N}$-acetyl-glucosamine (NAG) residues within chitin chains, or as lysozymes (EC: 3.2.1.17) cutting peptidoglycans between $\mathrm{N}$-acetylmuramic acid and NAG residues. Besides, a number of papers [20,21] pointed out that some GH19 proteins are coded by single genes or modular multi-domain lytic gene cassettes in bacteriophages or prophages. A few of these enzymes have been biochemically characterized and classified as endolysins with lysozyme-like properties [22-27]. Endolysins are produced in the late phases of the bacteriophage's lytic cycle and attack the peptidoglycan polymer of the host cell wall, thus allowing for the release of the phage progeny. Recently, a revised classification of GH19 proteins was implemented based on all sequences and biochemical data available in public databases and integrated with evolutionary issues, with the aim to ease the annotation of novel GH19 sequences from genomes and metagenomes, thus making the discovery of new GH19 enzymes of interest for application in biotechnology easier (https://gh19ed.biocatnet.de). In particular, endolysins are under investigation as specific antimicrobial candidates towards Gram-positive bacteria in the frame of the quest for new antibacterial drugs to fight drug resistance [28]. Recent developments raised expectations also for a possible use against Gram-negative bacteria [29].

In this study, we report the biochemical features and the evolution of two cold-active and thermosensitive GH19 hydrolases identified in the genome of an Antarctic marine Pseudomonas strain $[30,31]$ and address the functional differences between the two by bioinformatics analysis. To the best of our knowledge, this is the first experimental description of cold-active GH19 proteins.

\section{Results}

\subsection{Mining and Molecular Evolution of Glycoside Hydrolases from the Bacterial Isolate}

The source strain Pseudomonas Ef1 was isolated from a microbial consortium previously collected at Terra Nova Bay [30,32] and classified on the basis of its $16 \mathrm{~S}$ rDNA sequence [30].

Scanning of the Pseudomonas Ef1 annotated genome [28] led to the identification of two putative glycosyl hydrolase coding sequences named lys177 (531 bp) and lys188 (564 bp). Orthologous genes of both lys177 and lys188 were identified in the genomes of P. koreensis D-26, P. moravensis BS3668, and P. koreensis IMBL1 (Table 1). Lys177 and lys188 share $100 \%$ identity with the respective orthologues from P. koreensis D-26, a thermosensitive strain isolated from South Korean paddies [33]. Identity to P. moravensis BS3668 (strain of unknown origin) genes is $91.53 \%$ (lys177) and $89.51 \%$ (lys 188 ), while the identity to sequences from P. koreensis IMBL1, a strain isolated from South Africa, is $94.53 \%$ (lys177) and 87.27\% (lys188), respectively. These results suggest a close relationship of Pseudomonas Ef1 with $P$. koreensis D-26, supported also by the high identity shared by their $16 \mathrm{~S}$ rDNA sequences (Table 1). It is worth noticing that $P$. fluorescens $90 \mathrm{f} 12-2$ (16S rDNA sequence $99.93 \%$ identical to that of Pseudomonas Ef1) lacks the orthologous of Lys 177, as other more distantly related Pseudomonas strains. This observation hints to the occurrence of independent phage infections for the integration of 
phage enzymes into the Pseudomonas genomes. According to Phaster (PHAge Search Tool Enhanced Release) [34], both the lys177 and the lys188 coding sequences are inserted within different and complete prophagic regions of the Pseudomonas host.

Table 1. Pairwise identity (\%) of lys177 and lys188 to each other and to their orthologous genes, identified in Pseudomonas genomes collected from GenBank. Full-length pairwise identity (\%) of $16 \mathrm{~S}$ rRNA genes is also reported.

\begin{tabular}{|c|c|c|c|c|}
\hline Species & $\begin{array}{c}\text { Pairwise } \\
\text { Identity }(\%) \text { to } \\
\text { lys188 }\end{array}$ & $\begin{array}{c}\text { Pairwise } \\
\text { Identity (\%) } \\
\text { to lys177 }\end{array}$ & $\begin{array}{c}\text { Pairwise } \\
\text { Identity }(\%) \text { to } \\
\text { Pseudomonas Ef1 } \\
\text { 16S }\end{array}$ & $\begin{array}{c}\text { RefSeq Genome } \\
\text { Assembly } \\
\text { (GenBank AN) }\end{array}$ \\
\hline $\begin{array}{l}\text { Pseudomonas Ef1 } \\
\text { (paralogue gene) }\end{array}$ & $61.92^{a}$ & $61.92^{a}$ & 100 & GCF_007293365.1 \\
\hline $\begin{array}{c}\text { Pseudomonas } \\
\text { fluorescens 90f12-2 }\end{array}$ & 93.65 & - & 99.93 & GCF_003732335.1 \\
\hline $\begin{array}{l}\text { Pseudomonas } \\
\text { koreensis D26 }\end{array}$ & 100 & 100 & 99.87 & GCF_001605965.1 \\
\hline $\begin{array}{c}\text { Pseudomonas } \\
\text { moravensis BS3668 }\end{array}$ & 91.53 & 89.51 & 99.87 & GCF_900105805.1 \\
\hline $\begin{array}{c}\text { Pseudomonas } \\
\text { koreensis IMBL1 }\end{array}$ & 94.53 & 87.27 & 99.8 & GCF_001856885.1 \\
\hline $\begin{array}{c}\text { Pseudomonas } \\
\text { koreensis BS3658 b }\end{array}$ & 83.6 & - & 99.8 & GCF_900101415.1 \\
\hline $\begin{array}{c}\text { Pseudomonas } \\
\text { koreensis CRS05-R5 }\end{array}$ & 83.6 & - & 99.8 & GCF_001654515.1 \\
\hline $\begin{array}{l}\text { Pseudomonas sp } \\
{\text { RIT } 288^{\mathrm{b}}}\end{array}$ & 84.83 & - & 99.67 & GCF_000631985.1 \\
\hline $\begin{array}{c}\text { Pseudomonas } \\
\text { granadiensis LMG } \\
27940\end{array}$ & 84.13 & - & 99.54 & GCF_900105485.1 \\
\hline $\begin{array}{l}\text { Pseudomonas } \\
\text { reinekei MT1 }\end{array}$ & 78.48 & - & 99.54 & GCF_001945365.1 \\
\hline $\begin{array}{l}\text { Pseudomonas } \\
\text { koreensis CI12 }\end{array}$ & 82.19 & - & 98.96 & GCF_002003425.1 \\
\hline $\begin{array}{c}\text { Pseudomonas } \\
\text { koreensis P2 }\end{array}$ & 68.08 & - & 98.24 & GCF_002177125.1 \\
\hline $\begin{array}{c}\text { Pseudomonas putida } \\
\text { NBRC } 14164\end{array}$ & - & - & 97.98 & GCF_000412675.1 \\
\hline $\begin{array}{l}\text { Pseudomonas } \\
\text { viridiflava }\end{array}$ & - & - & 96.54 & GCF_900184295.1 \\
\hline $\begin{array}{c}\text { Pseudomonas } \\
\text { aeruginosa PA96 }\end{array}$ & - & - & 95.43 & GCF_000626655.2 \\
\hline
\end{tabular}

The closest match of the deduced amino acid sequences in the UniProtKB/Swiss-Prot database is the GH19 Endolysin A from Mycobacterium phage D29 (AN O64203), whose catalytic domain is 37\% and 36.8\% identical to LYS177 and LYS188, respectively. Signal peptides were not identified.

The evolution of the two sequences within the GH19 family was studied by Bayesian phylogenetic analysis limited to the group of GH19 sequences present in the CAZy and UniProt databases and annotated with biochemical data. We identified five major monophyletic clusters consistent with 
specific functional and taxonomic groups (Figure 1). Four of them include bacterial chitinases, chitinases from Proteobacteria, and two clusters of plant chitinases differing in the number of substrate binding loops (named with the terms "loopfull" and "loopless" according to [35]). A fifth group contains only phage/prophage endolysins with lysozyme activity. LYS177 and LYS188 nest in this group, suggesting they originated from phage sequences integrated in the Pseudomonas genome.

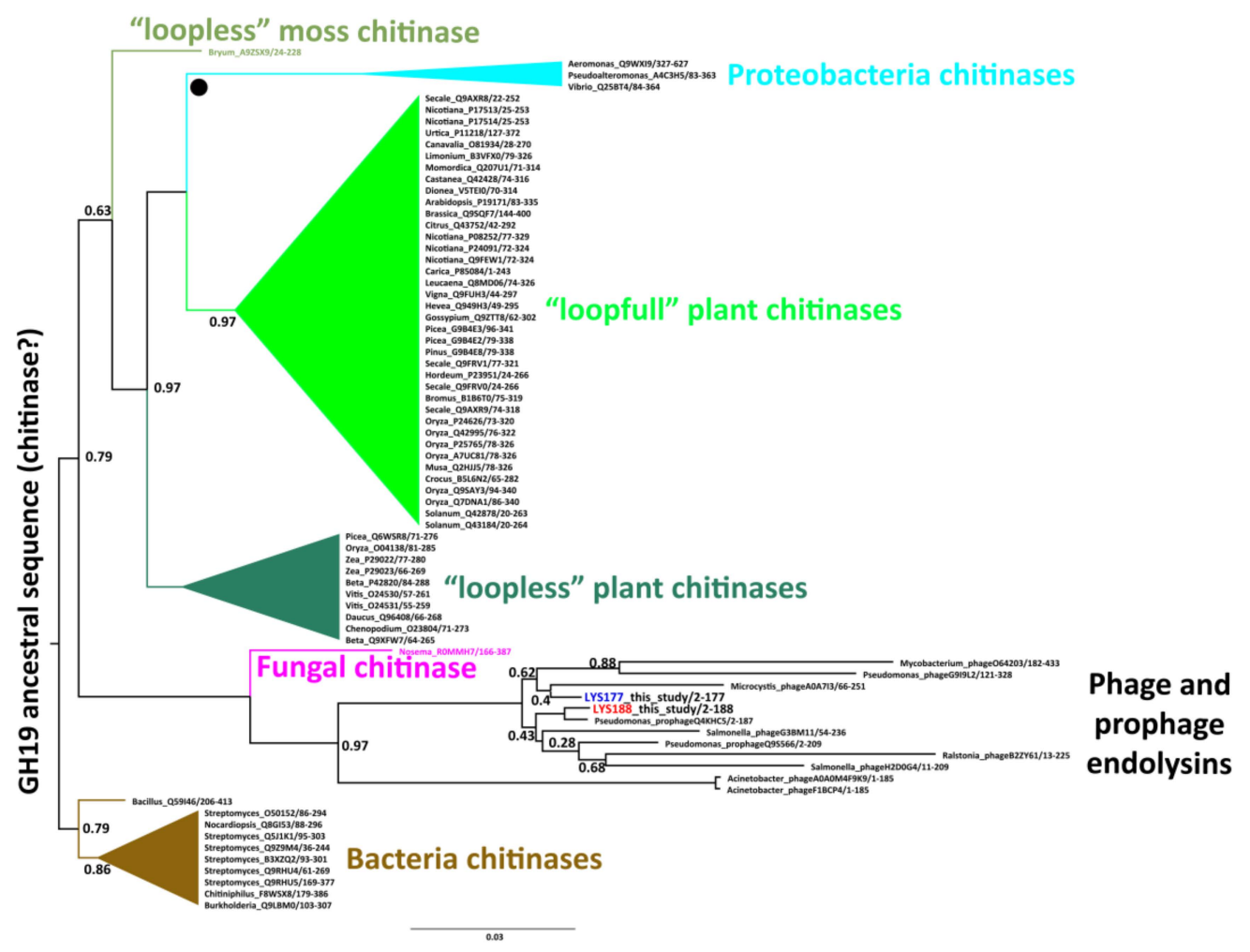

Figure 1. Rooted phylogenetic tree of characterized GH19 proteins. Each tip name represents the organism genus separated by an underscore from the Uniprot AN and by a slash from the sequence start and end position. In the endolysins cluster, the two sequences considered in this study are highlighted in blue and red. Other clusters/tips are coded by different colors and their internal relationships are collapsed for visualization purposes. "•" indicates a hypothetical horizontal gene transfer event. Decimal numbers at internal nodes indicate posterior probabilities only if lower than 1 . The branch lengths are proportional to the expected number of substitutions per site.

\subsection{LYS177 and LYS188 are Cold-Active Thermolabile Glycosidases with Lysozyme Activity}

The yield of recombinant His-tagged LYS177 and LYS188 (Figure S1), determined after affinity chromatography purification and two buffer exchange steps, was $\approx 2.5$ and $\approx 1 \mathrm{mg}$ per $100 \mathrm{~mL}$ of culture.

Since the GH19 family groups proteins classified either as chitinases or lysozymes ([36] and Figure 1), we assayed recombinant proteins for both activities using the protocols described in the materials and methods section. In the lysozyme-specific assay, the $\mathrm{pH}_{\mathrm{opt}}$ of LYS177 was 6.5 (Figure 2A) and the highest activity was recorded at $35^{\circ} \mathrm{C}$ (Figure 2B). Under optimal reaction conditions, the enzyme-specific activity was $1877 \pm 99 \mathrm{U} / \mathrm{mg}$. Moreover, LYS177 retained $40 \%$ activity at $5{ }^{\circ} \mathrm{C}$, a hallmark of cold activity. Under the same conditions, the activity of LYS188 was too low to be reliably calculated. For this reason, the buffer concentration was lowered to $50 \mathrm{mM}$, in order to increase the assay sensitivity [37]. $\mathrm{pH}_{\mathrm{opt}}$ and residual activity at the low temperature did match those displayed by LYS177, while the temperature supporting the highest activity was close to $25^{\circ} \mathrm{C}$. LYS188 temperature-dependent loss of activity was sharper, with only $30 \%$ residual activity at $35^{\circ} \mathrm{C}$. Specific activity under optimal conditions was $142 \pm 20 \mathrm{U} / \mathrm{mg}$. Furthermore, endo-chitinase and $N$-Acetyl- $\beta$-glucosaminidase activities, which is the ability to hydrolyze chito-oligosaccharides either at 
random positions or at the end of the chain, respectively, were assayed using the standard chitinolytic cocktail from Streptomyces griseus as the reference. Neither LYS177 nor LYS188 displayed N-acetyl glucosaminidase activity, while traces of endo-chitinase activity were measured (10.5 \pm 1.8 and $12.2 \pm 2.1$, respectively). However, the values determined were over three orders of magnitude lower than that performed by the commercial Streptomyces chitinase $(22620 \pm 150)$, and similar to those measured for hen egg white lysozyme $(8.6 \pm 0.7)$, which is reported to be endowed with a faint activity on chitooligosaccharides [38]. Moreover, LYS177 (but not LYS188) displayed antimicrobial activity on growing cultures of Gram-positive bacteria (Figure S2).
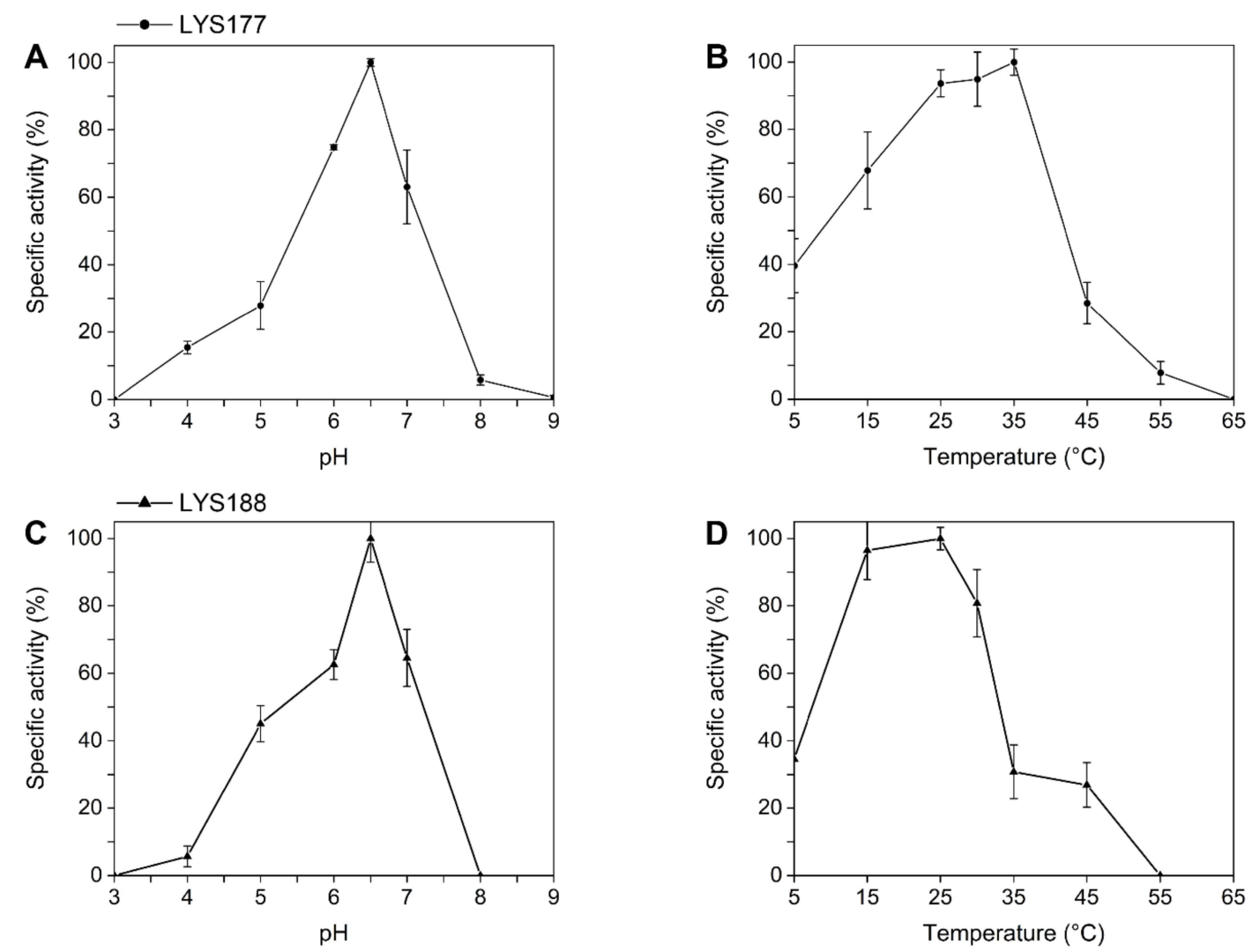

Figure 2. $\mathrm{pH}$ and temperature dependence. The effects of $\mathrm{pH}(\mathbf{A}, \mathbf{C})$ and of temperature $(\mathbf{B}, \mathbf{D})$ on the specific activity of LYS177 and LYS188 were detected by means of a turbidimetric lysis assay with $M$. lisodeikticus cells. Error bars indicate standard deviations of three independent biological replicates.

The enzymes' secondary structure was investigated by circular dichroism performed at $5{ }^{\circ} \mathrm{C}$, to take into account that both proteins are temperature sensitive (Figure $3 \mathrm{~A}, \mathrm{C}$ ). CD spectra displayed a bimodal shape, with two local minima at ca. 208 and $222 \mathrm{~nm}$. The observation that the minimum peak at $222 \mathrm{~nm}$ was slightly more negative than that at $208 \mathrm{~nm}$ suggested (according to [39]) the abundance of $\alpha$-helices and strong inter-helix interactions. These data are consistent with mainly alpha compact globular domains. The secondary structure content of both enzymes progressively decreased with the temperature. Above $45^{\circ} \mathrm{C}$, the $\mathrm{CD}$ signal dropped abruptly because of protein aggregation, which was also detectable as macroscopic precipitates in the cuvette. $\mathrm{T}_{\mathrm{m}}$, determined at a fixed $222 \mathrm{~nm}$ wavelength, was ca. $52^{\circ} \mathrm{C}$ for LYS177 and ca. $45^{\circ} \mathrm{C}$ for LYS188 (Figure 3B,D). 

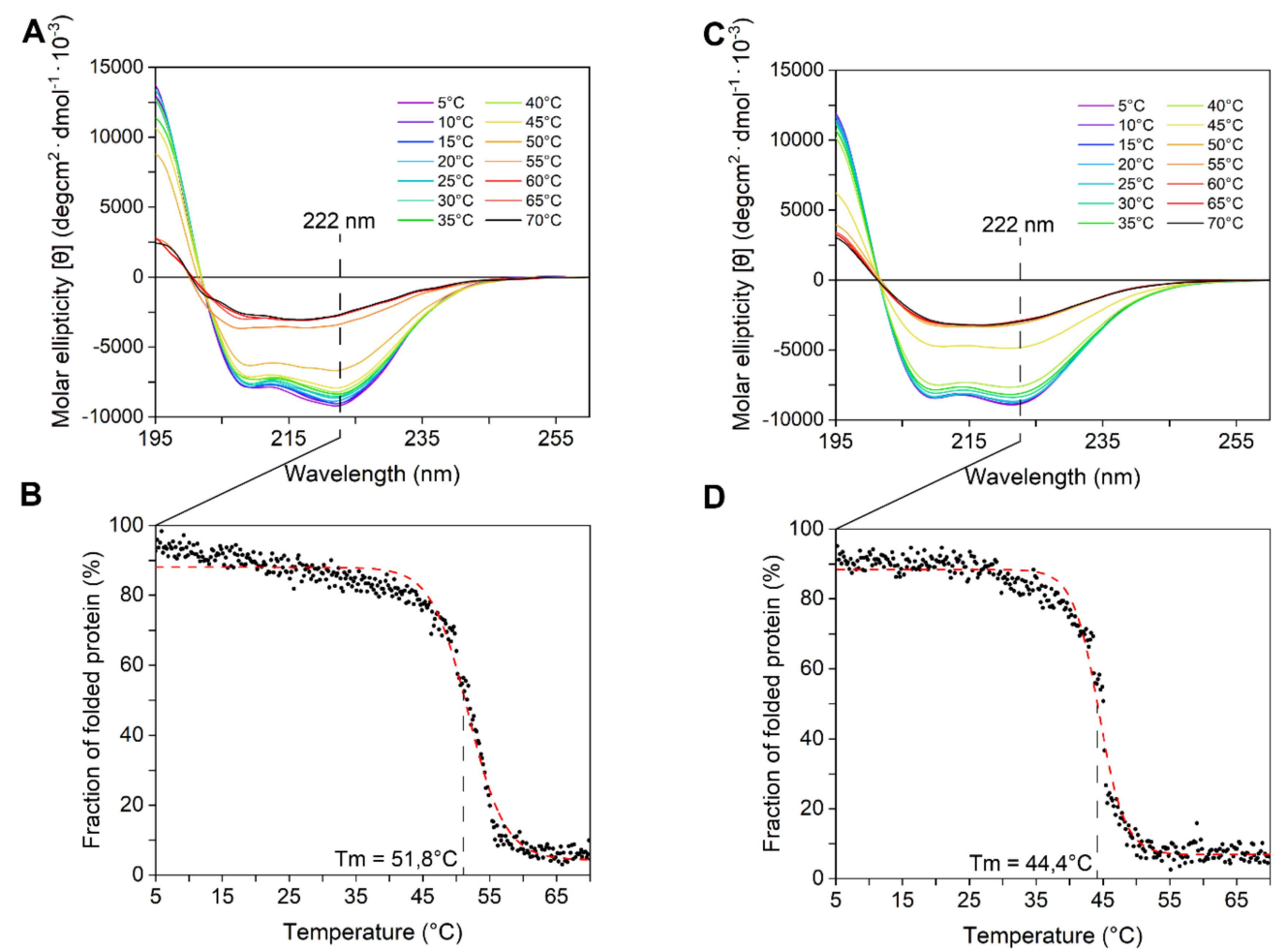

Figure 3. CD spectroscopy analysis. Far-UV CD spectra of LYS177 (A) and LYS188 (C) recorded at different temperatures. Thermal unfolding of LYS177 (B) and LYS188 (D) measured at a fixed $222 \mathrm{~nm}$ wavelength during heating from 5 to $70{ }^{\circ} \mathrm{C}$. Initial CD signal was taken as $100 \%$ for normalization. The Boltzmann fitting was used to estimate $\mathrm{T}_{\mathrm{m}}$. Data are the average of three independent experiments.

To monitor the effects of temperature over time, the residual activity and residual secondary structure of enzymes, previously exposed to 4,20 , and $37^{\circ} \mathrm{C}$ for $30 \mathrm{~min}$ up to several days, were measured (Figure 4). In this assay, aimed to assess heat robustness, LYS 177 displayed a peculiar behavior in the first $30 \mathrm{~min}$ of the experiment, with a marked drop of activity not accompanied by obvious changes in the secondary structure. This observation is puzzling since under the same conditions, both the activity and structure were unaltered in LYS188, which is less active in absolute values and less stable. In the absence of structural data, we can only hypothesize a fast and/or different rearrangement of a highly flexible region of LYS177 taking place at the very beginning of the experiment (see next section). After this, at $4{ }^{\circ} \mathrm{C}$, the two enzymes were stable for several days, while at 20 and $37^{\circ} \mathrm{C}$, that is under conditions permissive for most proteins but challenging for thermosensitive cold-active enzymes, the activity and secondary structure decreased over time (Figure 4B,C). LYS188 was confirmed to be less robust than LYS177, with half lives of 3 days at $20^{\circ} \mathrm{C}$ and 0.5 days at $37^{\circ} \mathrm{C}$ vs. 8 and 2 days recorded for LYS177 (Figure 4B,C). 

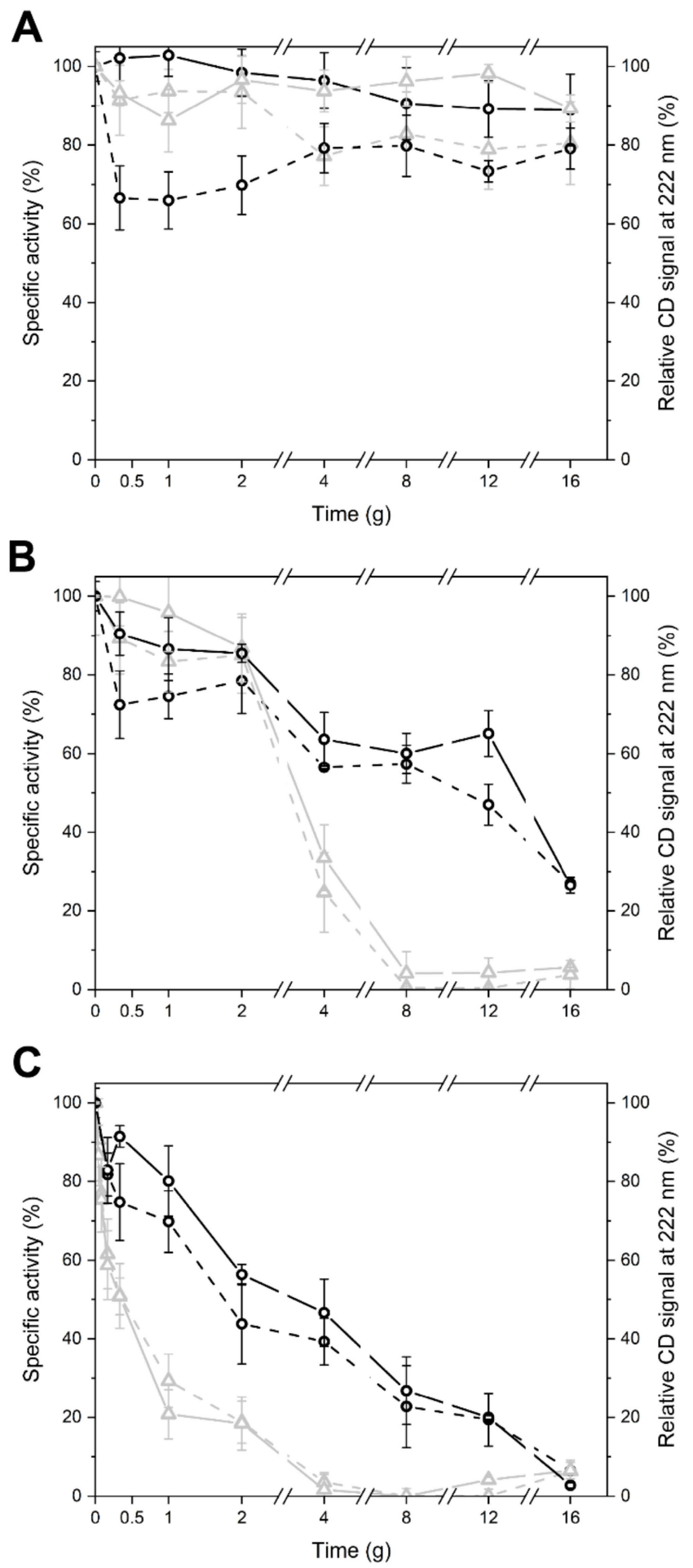

Figure 4. Thermal Stability of LYS177 and LYS188. Relative specific activity (dashed lines) and relative CD signal at $222 \mathrm{~nm}$ (continuous lines) of LYS 177 (black circles) and LYS 188 (grey triangles) incubated at $4(\mathbf{A}), 25(\mathbf{B})$, and $37^{\circ} \mathrm{C}(\mathbf{C})$.

\subsection{Specific Sequence Signatures May Account for Differences in Heat Stability}

The issue of the different stability towards temperature shown by the two enzymes was addressed by bioinformatics analysis. The first step was the search for specific sequence signatures. To this aim, the recently established GH19 Engineering Database (accessible at https://gh19ed.biocatnet.de; [40]), 
which contains manually curated annotations and a sequence-based classification of proteins containing a GH19 domain, was used to extract annotations and to download other putative endolysins from the homologous family "Pseudomonas prophage like". In total, 12 sequences from this family were closely related to LYS177 and 82 to LYS188. The resulting multiple alignment is shown in Figure S3. For the sake of simplicity, Figure 5A presents only the LYS177-LYS188 pairwise alignment, yet retaining information and annotations provided by the multiple alignment. LYS sequences share the two catalytic glutamate residues (Glu-51 and Glu-60) and the water coordination residue (Thr-97 for LYS177 and Thr-101 for LYS188), as well as another six residues predicted to be involved in substrate binding from subsite -2 to +1 , which are part of the substrate binding "core" conserved in all GH19s (https://gh19ed.biocatnet.de). In the multiple alignment, sequences clustered in two groups, according to the similarity to either LYS177 or LYS188, that differ from each other in a specific region, located right downstream from the catalytic residues and marked in Figure 5 as the "unaligned region". This region covers amino acids 62-76 of LYS177 and 62-78 of LYS188. Moreover, three different small insertions are present in LYS188, two including a couple of residues (83-84 and 117-118) and the third formed by five C-terminal residues. Positions quoted are highlighted on the 3-D models shown in Figure 5B,C.

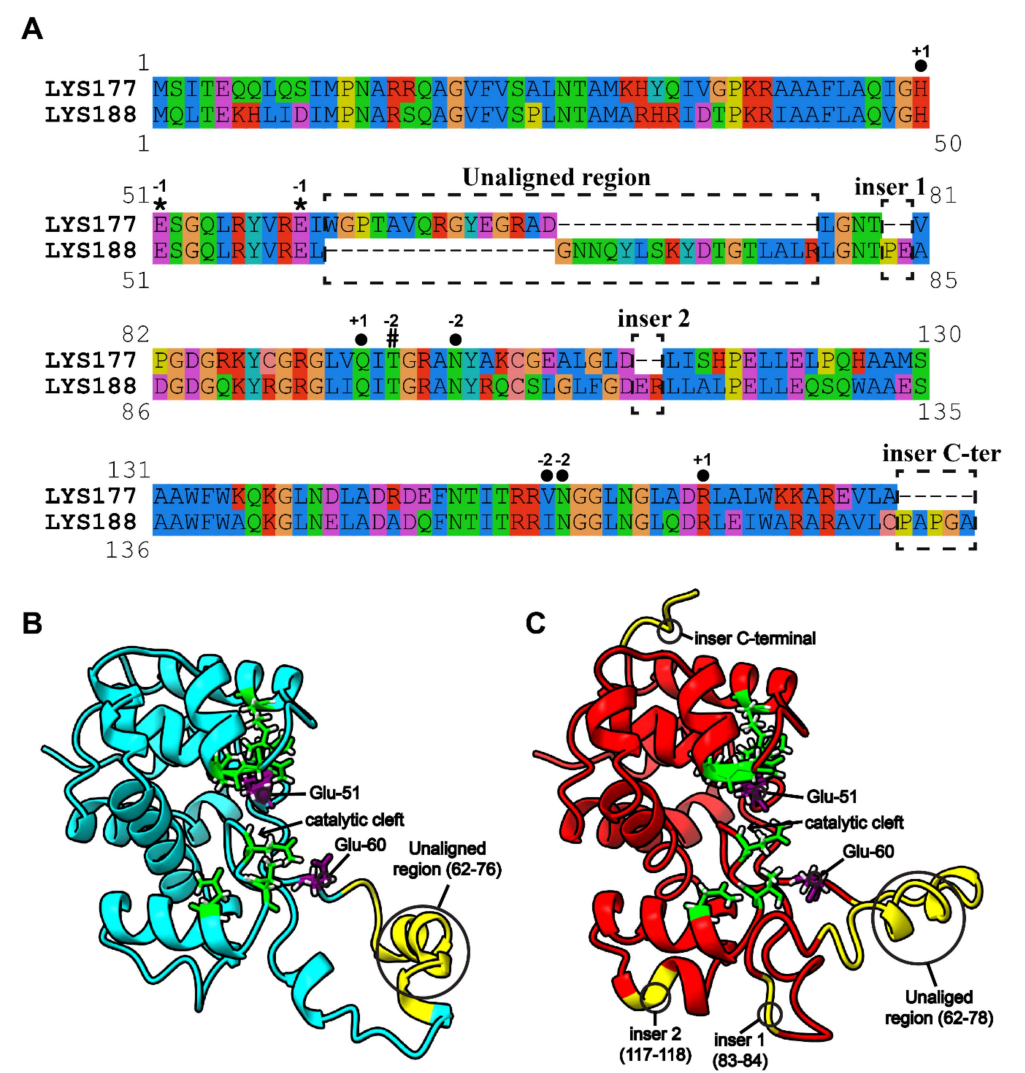

Figure 5. Pairwise alignment and predicted structures. (A) Pairwise alignment of LYS177 and LYS188, extracted from the multiple sequence alignment, including close homologues of both enzymes (Figure S3). Annotations of functional relevant sites conserved in the alignment were extracted from the sequences annotated in the GH19 engineering database (accessible at https://gh19ed.biocatnet.de: Sequence ID is 12,365 for LYS177 and 11,988 for LYS188) and marked, as follows, *: catalytic residues; \#: water coordination residue; $\bullet$ : substrate binding residues. Numbers indicate the subsite occupied by the sugar moiety predicted to interact with that residue, according the nomenclature reported in [41]. Unaligned/insertion regions are highlighted by dashed boxes. 3-D models of LYS177 (B) and LYS188 (C) are shown in cyan and red cartoons, respectively. Catalytic glutamate residues are shown as purple sticks. Other residues conserved in the catalytic core are shown as green sticks. Unaligned/insertion regions between close homologues of LYS177 and LYS188 are colored in yellow. 
Basic features of the enzymes structural dynamics were collected to predict flexibility and aggregation propensity at different temperatures. Corresponding regions in the two models (from 61 to 83 for LYS177 and 61 to 86 from LYS188) were refined by 40 ns MD simulations, while restraining other positions of the structure, as they could not be aligned to the sequence and structure of SPN1S endolysin (Figure S4), which is the closest match $(\approx 39 \%$ identity) with known 3 -D structure. Molecular dynamics (MD) simulations were performed at 4 and $25^{\circ} \mathrm{C}$. The values of per-residue root mean square fluctuations (RMSFs) and the average Aggrescan3D score (A3DS) were calculated over the MD simulation frames, to be used as predictors of per-residue flexibility and per-residue aggregation propensity, respectively. MD simulations of LYS177 at 4 and $25{ }^{\circ} \mathrm{C}$ (Figure 6A,B) suggest that, besides the expected slight increase of the average RMSF with temperature, the "unaligned region" (62-76) is the protein stretch that undergoes the higher increase in flexibility upon heating. Moreover, at $25^{\circ} \mathrm{C}$, Ile-61 and Trp-62 acquire a value A3DS $>1$ in the aggregation analysis that predicts a hotspot of aggregation. In LYS188 simulations (Figure 6C,D), the overall RMSF increase at $25{ }^{\circ} \mathrm{C}$ is higher than the one predicted for LYS177 as a consequence of a larger RMSF increase predicted at the 79-90 region (corresponding to 77-85 of LYS177), which includes the insertion 1 (83-84, Figure 5). The increase in flexibility of the "unaligned region" (62-78) is similar to that of LYS177 at $25^{\circ} \mathrm{C}$. Contrary to LYS177, in LYS188, a hotspot for aggregation is found at both temperatures just at the end of the "unaligned region" (Leu-77). At $25^{\circ} \mathrm{C}$, this residue and the other residues in close proximity form a predicted aggregation hotspot, which is more flexible than the aggregation hotspot found in LYS177 (Ile-61, Trp-62) at the same temperature. Moreover, other two LYS188 residues have A3DS > 1: Phe-114 at both temperatures and Leu- 113 only at $25^{\circ} \mathrm{C}$.

A

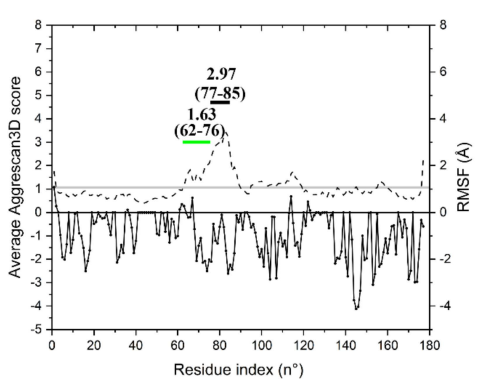

C

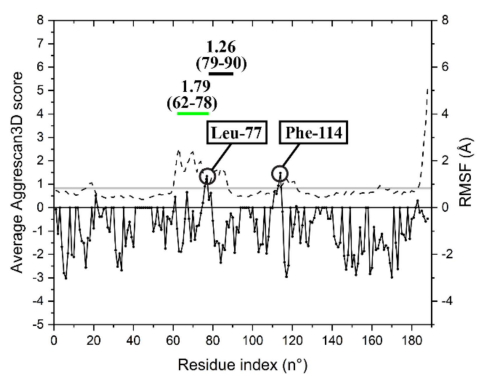

B

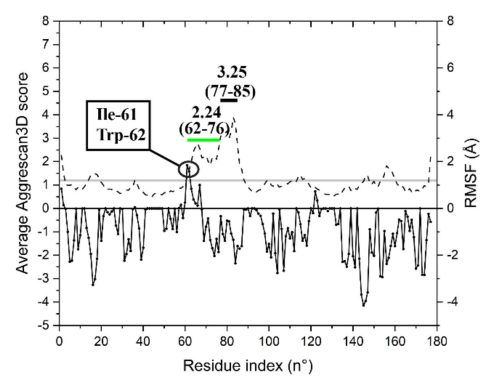

D

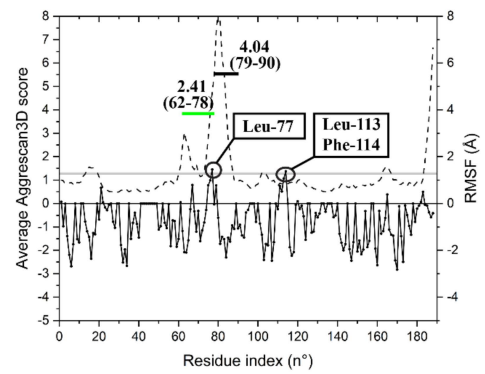

Figure 6. Per residue average Aggrescan3D score and RMSF. MD simulations of LYS177 at 5 (A) and $25^{\circ} \mathrm{C}(\mathrm{B})$ and of LYS188 at 5 (C) and $25^{\circ} \mathrm{C}$ (D). The black line with filled circular symbols indicates per-residue average Aggrescan3D scores; residues with score $>1$ are marked. The black dashed line indicates per-residue RMSF. The overall average RMSF is shown as a horizontal grey bar. The green horizontal bar marks the "unaligned region". The black bar indicates the sequence region immediately downstream. The two numbers in parentheses above each bar show the range of residues involved. The number above each parenthesis is the average RMSF of the amino acid stretch. 


\section{Discussion}

The two GH19 glycoside hydrolases described in this paper are associated to different prophagic regions of the same Antarctic Pseudomonas species. Both are endowed with lysozyme activity and are evolutionarily nested in a group of sequences characterized as phage endolysins. Overall, collected data supports the hypothesis they are phage enzymes integrated into the Pseudomonas Ef1 genome by independent and temporally separated phage infection events. This hypothesis is supported by the data reported in Table 1, suggesting that lys188 transfer preceded that of lys177, which is present only in the genomes of closely related Pseudomonas species. The high sequence identity of lys 177 and lys188 genes with $P$. koreensis D-26 sequences pinpoints that both sequences may have integrated in the common ancestor of the two strains before the break-up of the Sino-Korean Craton (which also includes the southern parts of the Korean Peninsula) from core Gondwana. The separation of South Korea from Gondwanaland started by the end of the Ordovician (nearly 400 mya) [42], long before the geographical isolation of the Antarctic continent from Gondwana and the formation of the Polar Front, which is a more recent geological event, dating over 60 mya ago [43].

Based on the GH19 tree topology, we can hypothesize that the common ancestor of GH19 proteins was most likely a chitinolytic enzyme, while lysozyme activity arose later. Our analysis does not allow to infer the type of organism that harbored the common ancestor of all GH19s, because the first bifurcation from the tree root is between proteins mainly from Actinobacteria and those from a composite group including bacterial, plant, phage, and fungal proteins. Nevertheless, data support the hypothesis of a more recent horizontal gene transfer from plants to Proteobacteria, forming a distinct lineage before the diversification of "loopfull" plant chitinases. The evolutionary scenario of the GH19 family presented in this work is different from the most recent family revision [44], as it does not surmise a plant origin and secondary transfer to bacteria. We are aware that, in the lack of a dated tree and a comprehensive sequence sampling, relevant elements are still missing for confirmation of the inferred rooting and horizontal gene transfer events. It may also be underlined that the large average pairwise distance $(\approx 60.1 \pm 7.3 \%)$ in the primary sequence among different clusters of characterized GH19 sequences emphasizes the poor biochemical information available about this protein family.

Both LYS177 and LYS188 proteins display lysozyme activity and conform to the canonical definition of cold adaptation, since they maintain high specific activity at low temperature. Both of them are temperature sensitive. Simulations suggest that an abrupt increase in flexibility of the "unaligned region" takes place in the heated system and may favor protein aggregation. Moreover, the marked heat sensitivity of LYS188 points to a possible effect of a nearby region, in which a small insertion, shared by all LYS188 close homologs, is present.

Therefore, our results highlight the role of amino acid stretches at the surface of LYS177 and LYS188 in modulating flexibility and likely heat instability of the two proteins, in agreement with the suggestions of previous computational studies that related protein cold adaptation to increased polypeptide flexibility in surface regions far away from the active site [45]. Such sequence patterns are conserved in some orthologous sequences (GH19 family, $>80 \%$ sequence identity) from organisms adapted to temperate environments. Moreover, the typical features of cold-active enzymes are shared by some GH19 endolysins from mesophilic phages, i.e., ABgp46 from an Acinetobacter phage [27]. Such observations may suggest a lack of selective pressure for maintaining or increasing the thermal stability of viral endolysins. As a matter of fact, endolysins are "one-shot" cell wall-degrading tools for the release of progeny virions [46]. On this ground, the hypothesis might be drawn that low stability could have been adopted as a possible strategy to avoid cell lysis, eventually caused by a long-term persistence of released active endolysins, of other bacterial hosts prior to phage infection.

The "unaligned" region is the more remarkable difference between LYS177 and LYS188. Its plastic nature is further supported by the comparison with other related GH19 endolysins (Figure S6), showing that this region is topologically equivalent to a three-helix module involved in peptidoglycan affinity in the Salmonella typhimurium phage endolysin [47]. The absence of relevant substrate binding sites in this region and the structural differences observed in the 3-D models rule out a relevant 
role in catalysis. Rather, it may be hypothesized a contribution of this stretch of amino acids in enzymes affinity toward different types of peptidoglycan modifications, which would explain the differences in activity of LYS177 and LYS188 on the peptidoglycan substrate. In this conceptual frame, it is tempting to hypothesize a possible role of the "unaligned" region in the co-evolutionary phage-host interactions [48] within the group of GH19 endolysins.

\section{Materials and Methods}

\subsection{Identification of the Bacterial Strain and of Glycoside Hydrolases Sequences}

Pseudomonas Ef1 is a Gram-negative bacterium that was isolated from the microbial consortium previously described as associated to the psychrophilic Antarctic ciliate Euplotes focardii [32].

In order to assess the taxonomic position of this strain with respect to other Pseudomonas species, the $16 \mathrm{~S}$ rRNA gene was amplified from the genomic DNA by PCR using bacterial universal degenerate primers 27F (5'-AGAGTTTGATCMTGGCTCAG $\left.3^{\prime}\right)$ and 1492R (5'-TACGGYTACCTTGTTACGACTT $\left.3^{\prime}\right)$, as the forward and reverse primer, respectively. Amplification was in a Biometra Thermal Cycler (Biometra Ltd., Kent, UK) with the following cycling conditions: initial denaturation at $94{ }^{\circ} \mathrm{C}$ for $5 \mathrm{~min}$, 30 cycles of $1 \mathrm{~min}$ denaturation at $94{ }^{\circ} \mathrm{C}$, annealing at $60{ }^{\circ} \mathrm{C}$ for $1 \mathrm{~min}$, and extension at $72{ }^{\circ} \mathrm{C}$ for $1 \mathrm{~min}$. A final extension step was at $72{ }^{\circ} \mathrm{C}$ for $5 \mathrm{~min}$. Sanger sequencing of the $16 \mathrm{~S}$ rRNA amplicon was performed by BMR Genomics (Padova, Italy). The rRNA sequence was used as query for a Blastn search on the NCBI data bank (http://blast.ncbi.nlm.nih.gov).

Glycoside hydrolase sequences were identified in the genome deposited in GenBank under the Accession Number (AN) VAUR00000000 by the pipeline available in Prokka 1.12 [49], with the dbCAN database of carbohydrate active enzymes as a reference (http://csbl.bmb.uga.edu/dbCAN). The sequences identified as GH19 were named lys177 and lys188 (lys stands for lysozyme and the numbers stand for the amino acid length of the predicted protein sequences). A similar approach was used to annotate the genomes of other Pseudomonas species collected from GenBank, to identify orthologues of ly177 and lys188.

SignalP 5 (http://www.cbs.dtu.dk/services/SignalP/; [50]) was used for detecting the presence of signal peptides. The genome of the isolated strain was scan-searched with Phaster [34] to investigate the possible location of genes within prophagic regions.

\subsection{Enzymes Expression and Purification}

The lys177 and lys188 gene sequences were codon optimized for expression in E. coli, synthesized and cloned into pET-21a expression vector by GenScript USA Inc. (Piscataway, NJ 08854, USA). Both genes are flanked by NdeI and XhoI restriction sites, and harbor 18 supplemental nucleotides for 6xHis-Tag at their C-terminus. The expression vector was transformed in E. coli DH5 $\alpha$ (EMD Millipore, Billerica, MA, USA) for amplification and then transferred into E. coli BL21[DE3] cells (EMD, Millipore, Billerica, MA, USA) for heterologous production. Transformants were grown overnight at $37^{\circ} \mathrm{C}$ in $2 \mathrm{~mL}$ of Lysogeny Broth $(\mathrm{LB}, 10 \mathrm{~g} / \mathrm{L}$ tryptone, $5 \mathrm{~g} / \mathrm{L}$ yeast extract, $5 \mathrm{~g} / \mathrm{L} \mathrm{NaCl}$ ) and then diluted 1:25 in $50 \mathrm{~mL}$ of Zym-5052 medium [51] and incubated overnight at $20^{\circ} \mathrm{C}$. Media contained ampicillin $100 \mathrm{mg} / \mathrm{L}$.

Recombinant His-tagged LYS177 and LYS188 were extracted as described in [52], and purified by immobilized-metal affinity chromatography (IMAC) on Ni/NTA agarose resin (Jena Bioscience, Jena, Germany) at $4{ }^{\circ} \mathrm{C}$ after two washing steps at 10 and $20 \mathrm{mM}$ imidazole and elution in $250 \mathrm{mM}$ imidazole, $\mathrm{pH}$ 8.0.

Protein concentration was determined by the protein Bradford assay (Bio-Rad, California, USA), using bovine serum albumin as a standard. Samples containing the highest protein concentrations were buffer exchanged twice by gel filtration on a PD10 column (GE Healthcare, Little Chalfont, UK) against $80 \mathrm{mM}$ potassium phosphate buffer, $\mathrm{pH} 6.5$. 
Whole-cell extracts, soluble and insoluble protein fractions, and IMAC purified fractions were loaded on $14 \%$ acrylamide Tris-Glycine SDS/PAGE with BLUeye Prestained Protein Ladder by GeneDirex Inc. as the standard. After electrophoresis, gels were stained with Coomassie dye (Bio-Rad).

\subsection{Enzymes Characterization}

\subsubsection{Lysozyme Activity Assay}

Lysozyme activity was measured spectrophotometrically in Euroclone Primo ${ }^{\circledR}$ Multiwell plates 96 (Pero, Italy), by a VICTOR Multilabel Plate Reader (PerkinElmer, Waltham, MA, USA). In total, $\approx 10 \mathrm{mg} / \mathrm{mL}$ cells of the Gram-positive bacterium Micrococcus lysodeikticus (Merck KGaA, Darmstadt, Germany) were suspended in $270 \mu \mathrm{L}$ of $80 \mathrm{mM}$ potassium phosphate buffer, $\mathrm{pH} 6.5$, so that in a single well, $\mathrm{A}_{600}$ was between 0.6 and 1 . In total, $30 \mu \mathrm{L}(\approx 2 \mu \mathrm{g})$ of enzyme solution were added to the reaction mix and mixed by pipetting. $\mathrm{A}_{600}$ was recorded at 10 -s intervals up to $10 \mathrm{~min}$. The slope of the linear regression between $\mathrm{A}_{600}$ and time (min) was used for the calculation of $\Delta \mathrm{A}_{600} / \mathrm{min}$. Reactions were carried out at $30^{\circ} \mathrm{C}$ and the PD10 buffer was used as a blank. In this assay, activity (U) is defined as the amount of enzyme that induces a decrease of $0.001 \mathrm{~A}_{600}$ per min, due to Micrococcus cell lysis following wall degradation elicited by the enzyme. Specific activity is defined here as U/mg normalized for the reaction volume, according to the formula presented in [53]. HEWL (Hen Egg White Lysozyme, Merck KGaA) was the positive control. Activity was recorded in the $3-9 \mathrm{pH}$ range and in the $5^{\circ} \mathrm{C}-65^{\circ} \mathrm{C}$ ( $\mathrm{pH}$ 6.5) temperature range. Measures were taken in biological and technical triplicates.

\subsubsection{Chitinase Assay}

Endo-chitinase activity was measured on the low-molecular-weight fluorimetric substrate 4-methylumbelliferyl $\beta$-D- $N, N^{\mathrm{I}}, N^{\mathrm{II}}$-triacetylchitotriose (4-MU chitotrioside) by Merck KGaA. In total, $25 \mu \mathrm{L}$ of $0.5 \mathrm{mM}(0.4 \mathrm{mg} / \mathrm{mL}) 4-\mathrm{MU}$ chitotrioside solution were added to $20 \mu \mathrm{L} 100 \mathrm{mM} \mathrm{K}$-phosphate (pH 5 or 6.5). Reactions started when $5 \mu \mathrm{L}$ of enzyme solution (containing either $5 \mu \mathrm{g}$ or $10 \mu \mathrm{g}$ enzyme) or the reaction buffer were added to the reaction mixture. After $1 \mathrm{~h}$ at $25^{\circ} \mathrm{C}, 100 \mu \mathrm{L}$ of sodium carbonate $0.4 \mathrm{M}$ were added to stop the reaction. Fluorescence emitted at $460 \mathrm{~nm}$ in $0.1 \mathrm{~s}$ by excitation at $355 \mathrm{~nm}$ was measured and specific activity determined as: $\frac{\left(F_{\text {enzyme }}-F_{\text {buffer }}\right)}{10^{3} \text { time }(\min ) \cdot m g_{\text {enzyme. }}}$. Further, $1 \mathrm{U} / \mathrm{mg}$ is the amount of activity per mg of enzyme able to release an amount of 4-MU that will produce a 1000 Approximate Units difference in fluorescence after $1 \mathrm{~h}$ in the above reaction mixture.

Chitinolytic activity was measured using the low-molecular-weight chromogenic substrate 4-nitrophenyl $N$-acetyl- $\beta$-D-glucosaminide (4-NP chitoside) by Merck KG aA. In total, $25 \mu \mathrm{L}$ of $4 \mathrm{mg} / \mathrm{mL}$ 4-NP chitoside solution were added to $20 \mu \mathrm{L} 100 \mathrm{mM}$ potassium phosphate buffer (pH 5 or 6.5). Reaction started when $5 \mu \mathrm{L}$ of enzyme solution (containing either $5 \mu \mathrm{g}$ or $10 \mu \mathrm{g}$ enzyme) or the reaction buffer were added to the reaction mixture. After $1 \mathrm{~h}$ at $25^{\circ} \mathrm{C}, 100 \mu \mathrm{L}$ of sodium carbonate $0.4 \mathrm{M}$ were added to stop the reaction. Measuring the $\mathrm{A}_{405}$ permitted calculation of the activity based on the molar extinction coefficient of released 4-nitrophenol at $\mathrm{pH} 10$. Further, $1 \mathrm{U} / \mathrm{mg}$ is the amount of activity per $\mathrm{mg}$ of enzyme that is able to release $1.0 \mu \mathrm{mol}$ of 4 -nitrophenol after $1 \mathrm{~h}$ of reaction. Each measure was in triplicate.

\subsubsection{Circular Dichroism (CD) Spectroscopy}

Measurements of protein samples $(6 \mu \mathrm{M})$ in $80 \mathrm{mM}$ potassium phosphate buffer $\mathrm{pH} 6.5$ were performed in biological triplicates at $4{ }^{\circ} \mathrm{C}$ by a spectropolarimeter J-815 (JASCO Corporation, Easton, PA, USA) in a 1-mm path-length cuvette at variable wavelength in the far-UV range (195-260 nm). Other parameters were: scanning speed $20 \mathrm{~nm} / \mathrm{min}$, bandwidth $1 \mathrm{~nm}$, digital integration time per data $2 \mathrm{~s}$, and data pitch $0.2 \mathrm{~nm}$. All spectra were corrected for buffer contribution, smoothed twice by the Means-Movement algorithm, and averaged among different biological replicates. 
Thermal denaturation spectra were obtained by measuring the CD signal at $222 \mathrm{~nm}$ fixed wavelength when progressively heating the sample from 5 to $70{ }^{\circ} \mathrm{C}$. Measurements were performed with a data pitch of $0.2^{\circ} \mathrm{C}$ and a temperature slope of $5^{\circ} \mathrm{C} / \mathrm{min}$.

Molar mean ellipticity per residue was calculated according to the formula:

$$
[\theta]=\frac{3300 m \cdot \Delta A}{c \cdot n \cdot l}
$$

where $\Delta A$ is the difference in the absorption between circularly polarized right and left light of the protein corrected for blank, $m$ is the protein molecular mass in Daltons, $l$ is the path length $(0.1 \mathrm{~cm})$, $c$ is the protein concentration in $\mathrm{mg} / \mathrm{mL}$, and $n$ is the number of residues [16]. Absolute CD signals were converted to percentage (\%) with respect to maximum and minimum values, and the scatterplot with temperature was fitted with a Boltzmann distribution to estimate the thermal denaturation midpoint $\left(\mathrm{T}_{\mathrm{m}}\right)$.

\subsubsection{Thermal Stability}

Relative lysozyme-specific activity and relative CD signal at $222 \mathrm{~nm}$ of the two enzyme preparations were determined after incubation at 4,20 , and $37^{\circ} \mathrm{C}$ at the $\mathrm{pH}$ optimum $\left(\mathrm{pH}_{\mathrm{opt}}\right)$ in $80 \mathrm{mM}$ potassium phosphate buffer. Measures were recorded at $25^{\circ} \mathrm{C}$ after 4,8 , and $24 \mathrm{~h}$ in the first day of incubation and then after day 2 and 4 , and every 4 days up to 16 days. If necessary, due to very low stability at $37{ }^{\circ} \mathrm{C}$, the values were also measured after 1,2 , and $12 \mathrm{~h}$. Results were averaged over three biological triplicates.

\subsection{In Silico Analysis}

\subsubsection{Phylogenetic Analysis}

Multiple alignments and phylogeny analysis were performed with a group of biochemically characterized GH19 selected from CAZy (http://www.cazy.org) and UniProt databases.

A starting approximate alignment was built with the E-ins-I algorithm of Mafft 7.313 [54]. All the accessory domains (not containing the GH19 catalytic domain) were then manually trimmed. A Bio-Neighbour Joining [55] starting tree was generated from this alignment through Phylogeny.fr web service (http://www.phylogeny.fr/one_task.cgi?task_type=bionj). These results were refined in a Bayesian analysis by Bali-Phy 3.4 [56]. Six independent Monte Carlo Markov chain analyses were run and stopped after 40,000 cycles, when sampled parameters reached convergence and good mixing according to the manual guidelines (http://www.bali-phy.org/README.html\#mixing_and_ convergence). In order to eliminate the background noise at the beginning of the run, the first $50 \%$ of samples was discarded. Each analysis was performed at default prior parameters, with the LG empirical substitution rate matrix [57] and the rs07 insertion/deletion model [58]. The resulting unrooted tree is the majority consensus from all the samples collected during runs.

The position of the root was inferred with a parsimony-based approach, minimizing the costs of duplication, transfer, and loss events under a defined species phylogeny by RANGER 2 [59], using the previously obtained unrooted phylogeny and a chronogram tree of the species in which each branch represents the evolutionary time. This tree was generated through the "Time Tree of Life" website (http://www.timetree.org/). Three different cost combinations for duplication (D), transfer $(\mathrm{T})$, and loss (L) ([D-T-L]: [2-3-1], [3-3-1], and [2-4-1]) were used to select the optimal position of the root. Each analysis was repeated 100 times. The position of the root was considered reliable if optimal (minimum number of costs) in all attempts.

\subsubsection{Alignment and Annotation of Close Homologues of LYS177 and LYS188}

The amino acid sequences of LYS177 and LYS188 were Blast searched against the GH19 Engineering Database (accessible at https://gh19ed.biocatnet.de, [40]) to annotate the sequences and extract the 
sequences of catalytic domains of other GH19s proteins belonging to the same homologous group. Sequences were clustered with CD-HIT [60] at 90\% identity to retrieve only closely related orthologous sequences, sharing at least 90\% identity with either LYS177 or LYS188. A multiple alignment of these sequences was obtained with the E-ins-I algorithm of Mafft 7.313 [54]. Aligned sites that changed according to a possible recent adaptation specific for LYS177 or LYS188 were inferred by comparing the closely related groups of the two sequences.

\subsubsection{Modelling and Molecular Dynamics (MD) Simulations}

Three-dimensional models of LYS177 and LYS188 were built by ITASSER web server [61]. The best models according to the ITASSER scoring scheme were visualized and structurally aligned, with UCSF ChimeraX 0.91 [62], to the closest match available in the PDB database, that is the Salmonella Typhimurium-infecting phage SPN1S endolysin (AN 4ok7; [47]).

The protonation states of titratable residues in the LYS177 and LYS188 models were obtained with PDB2PQR [63], estimating titration states with propka 3.1 [64] at $\mathrm{pH}$ 6.5. The hydrogenated complex was solvated in a dodecahedron box with a minimum distance of $15 \AA$ from the model and solvated with TIP4P parameterized explicit water molecules according to CHARMM36m forcefield parameters (updated March 2019), downloaded from http://mackerell.umaryland.edu/charmm_ff.shtml\#gromacs. $\mathrm{K}^{+}$and $\mathrm{Cl}^{-}$ions at a concentration of $80 \mathrm{mM}$ were added to neutralize the charge of the system. An MD simulation was performed in gromacs 2019.6 [65], after prior energy minimization and position-restrained equilibration in the solvent, as outlined by Lindahl for lysozyme in water [66]. The system was equilibrated in NPT conditions at a constant temperature of $4{ }^{\circ} \mathrm{C}$ (V-rescale thermostat) and constant pressure of $1 \mathrm{~atm}$ (Berendsen barostat), by scaling the center of mass of the reference coordinates with the scaling matrix of the pressure coupling. After equilibration, $40 \mathrm{~ns}$ refinement was performed for non-terminal region/s $>5 \mathrm{AA}$ in length, if not aligned in their primary sequence between LYS177 and LYS188, or if their modelled structure was not superposed to SPN1S endolysin (Figure S4): All heavy atoms of conserved regions were position restrained with a potential of $1000 \mathrm{~kJ} \mathrm{~mol}^{-1} \mathrm{~nm}^{-1}$. A simulated annealing protocol was used to heat the refined model equilibrated at $4{ }^{\circ} \mathrm{C}$, up to reach and equilibrate the same system also at $25^{\circ} \mathrm{C}$. Unbiased productive MD simulations with an integration step of $2 \mathrm{fs}$ (covalent bonds between hydrogens and heavy atoms were constrained) were performed at 4 and $25{ }^{\circ} \mathrm{C}$ (from respective equilibrated systems after refinement) for $200 \mathrm{~ns}$ at least, and continued until convergence of the RMSD values with respect to the starting structure was achieved (Figure S5), saving information on the system every $0.2 \mathrm{~ns}$.

Only the frames sampled in the last $100 \mathrm{~ns}$, after reaching equilibration, were used for calculating per residue RMSF and average aggregation propensity, predicted by applying the Aggrescan3D standalone package [67] to each sampled frame with a $10 \AA$ distance set for the aggregation analysis.

Supplementary Materials: The following are available online at http:/www.mdpi.com/1660-3397/18/11/579/ s1, Figure S1: SDS/PAGE of recombinant proteins purified by affinity chromatography (IMAC), Figure S2: Antimicrobial plate assay, Figure S3: Multiple alignment of LYS177, LYS188 and close homologues of both enzymes, Figure S4: Structural superposition of LYS177 and LYS188 ITASSER models to the 3D structure of Salmonella Typhimurium-infecting phage SPN1S endolysin (PDB AN 4ok7), Figure S5: Root mean square deviation of the MD simulations during the production run. Figure S6: Multiple alignment of LYS177, LYS188 and other phage homologues.

Author Contributions: M.O. carried out production and characterization of the recombinant proteins, in silico evolution and simulation analyses and edited the manuscript; S.P. performed genes prediction and analysis and revised the manuscript; M.L. conceived and supervised the project, wrote and revised the manuscript. All authors have read and approved the manuscript.

Funding: M.L. acknowledges support by FA (Fondo di Ateneo) of the University of Milano-Bicocca (grants 2015-ATE-0060, 2016-ATE-0134).

Acknowledgments: M.O. acknowledges a PhD fellowship by the University of Milano-Bicocca.

Conflicts of Interest: The authors declare no conflict of interest. The funders had no role in the design of the study; in the collection, analyses, or interpretation of data; in the writing of the manuscript, or in the decision to publish the results. 


\section{References}

1. D'Amico, S.; Collins, T.; Marx, J.C.; Feller, G.; Gerday, C. Psychrophilic microorganisms: Challenges for life. EMBO Rep. 2006, 7, 385-389. [CrossRef] [PubMed]

2. De Maayer, P.; Anderson, D.; Cary, C.; Cowan, D.A. Some like it cold: Understanding the survival strategies of psychrophiles. EMBO Rep. 2014, 15, 508-517. [CrossRef] [PubMed]

3. Feller, G.; Gerday, C. Psychrophilic enzymes: Hot topics in cold adaptation. Nat. Rev. Microbiol. 2003, 1, 200-208. [CrossRef] [PubMed]

4. Siddiqui, K.S.; Cavicchioli, R. Cold-adapted enzymes. Annu. Rev. Biochem. 2006, 75, 403-433. [CrossRef]

5. D'Amico, S.; Marx, J.-C.; Gerday, C.; Feller, G. Activity-stability relationships in extremophilic enzymes. J. Biol. Chem. 2003, 278, 7891-7896. [CrossRef]

6. Siddiqui, K.S.; Feller, G.; D’Amico, S.; Gerday, C.; Giaquinto, L.; Cavicchioli, R. The active site is the least stable structure in the unfolding pathway of a multidomain cold-adapted $\alpha$-amylase. J. Bacteriol. 2005, 187, 6197-6205. [CrossRef]

7. Mangiagalli, M.; Lapi, M.; Maione, S.; Orlando, M.; Brocca, S.; Pesce, A.; Barbiroli, A.; Camilloni, C.; Pucciarelli, S.; Lotti, M. The co-existence of cold activity and thermal stability in an Antarctic GH42 $\beta$-galactosidase relies on its hexameric quaternary arrangement. FEBS J. 2020. [CrossRef]

8. Santiago, M.; Ramírez-Sarmiento, C.A.; Zamora, R.A.; Parra, L.P. Discovery, molecular mechanisms, and industrial applications of cold-active enzymes. Front. Microbiol. 2016, 7, 1408. [CrossRef]

9. Mangiagalli, M.; Brocca, S.; Orlando, M.; Lotti, M. The "cold revolution". Present and future applications of cold-active enzymes and ice-binding proteins. New Biotechnol. 2020, 55, 5-11. [CrossRef]

10. Collins, T.; Margesin, R. Psychrophilic lifestyles: Mechanisms of adaptation and biotechnological tools. Appl. Microbiol. Biotechnol. 2019, 103, 2857-2871. [CrossRef]

11. Yang, G.; Aprile, L.; Turturo, V.; Pucciarelli, S.; Pucciarelli, S.; Miceli, C. Characterization and comparative analysis of psychrophilic and mesophilic alpha-amylases from Euplotes species: A contribution to the understanding of enzyme thermal adaptation. Biochem. Biophys. Res. Commun. 2013, 438, 715-720. [CrossRef] [PubMed]

12. Perfumo, A.; Banat, I.M.; Marchant, R. Going green and cold: Biosurfactants from low-temperature environments to biotechnology applications. Trends Biotechnol. 2018, 36, 277-289. [CrossRef] [PubMed]

13. John, M.S.; Nagoth, J.A.; Ramasamy, K.P.; Ballarini, P.; Mozzicafreddo, M.; Mancini, A.; Telatin, A.; Liò, P.; Giuli, G.; Natalello, A. Horizontal gene transfer and silver nanoparticles production in a new Marinomonas strain isolated from the Antarctic psychrophilic ciliate Euplotes focardii. Sci. Rep. 2020, 10, 1-14. [CrossRef] [PubMed]

14. Vallesi, A.; Pucciarelli, S.; Buonanno, F.; Fontana, A.; Mangiagalli, M. Bioactive molecules from protists: Perspectives in biotechnology. Eur. J. Protistol. 2020, 125720. [CrossRef] [PubMed]

15. Núñez-Pons, L.; Shilling, A.; Verde, C.; Baker, B.J.; Giordano, D. Marine Terpenoids from Polar Latitudes and Their Potential Applications in Biotechnology. Mar. Drugs 2020, 18, 401. [CrossRef]

16. Mangiagalli, M.; Bar-Dolev, M.; Tedesco, P.; Natalello, A.; Kaleda, A.; Brocca, S.; Pascale, D.; Pucciarelli, S.; Miceli, C.; Braslavsky, I. Cryo-protective effect of an ice-binding protein derived from Antarctic bacteria. FEBS J. 2017, 284, 163-177. [CrossRef]

17. Pischedda, A.; Ramasamy, K.P.; Mangiagalli, M.; Chiappori, F.; Milanesi, L.; Miceli, C.; Pucciarelli, S.; Lotti, M. Antarctic marine ciliates under stress: Superoxide dismutases from the psychrophilic Euplotes focardii are cold-active yet heat tolerant enzymes. Sci. Rep. 2018, 8, 14721. [CrossRef]

18. Lombard, V.; Golaconda Ramulu, H.; Drula, E.; Coutinho, P.M.; Henrissat, B. The carbohydrate-active enzymes database (CAZy) in 2013. Nucleic Acids Res. 2013, 42, D490-D495. [CrossRef]

19. Brameld, K.A.; Goddard, W.A. The role of enzyme distortion in the single displacement mechanism of family 19 chitinases. Proc. Natl. Acad. Sci. USA 1998, 95, 4276-4281. [CrossRef]

20. Oliveira, H.; Melo, L.D.; Santos, S.B.; Nóbrega, F.L.; Ferreira, E.C.; Cerca, N.; Azeredo, J.; Kluskens, L.D. Molecular aspects and comparative genomics of bacteriophage endolysins. J. Virol. 2013, 87, 4558-4570. [CrossRef]

21. Vidová, B.; Šramková, Z.; Tišáková, L.; Oravkinová, M.; Godány, A. Bioinformatics analysis of bacteriophage and prophage endolysin domains. Biologia 2014, 69, 541-556. [CrossRef] 
22. Lai, M.-J.; Lin, N.-T.; Hu, A.; Soo, P.-C.; Chen, L.-K.; Chen, L.-H.; Chang, K.-C. Antibacterial activity of Acinetobacter baumannii phage $\phi \mathrm{AB} 2$ endolysin (LysAB2) against both gram-positive and gram-negative bacteria. Appl. Microbiol. Biotechnol. 2011, 90, 529-539. [CrossRef] [PubMed]

23. Hosoda, N.; Kurokawa, Y.; Sako, Y.; Nagasaki, K.; Yoshida, T.; Hiroishi, S. The functional effect of Gly209 and Ile213 substitutions on lysozyme activity of family 19 chitinase encoded by cyanophage Ma-LMM01. Fish. Sci. 2011, 77, 665-670. [CrossRef]

24. Walmagh, M.; Briers, Y.; Dos Santos, S.B.; Azeredo, J.; Lavigne, R. Characterization of modular bacteriophage endolysins from Myoviridae phages OBP, 201 $2-1$ and PVP-SE1. PLoS ONE 2012, 7, e36991. [CrossRef] [PubMed]

25. Lim, J.-A.; Shin, H.; Kang, D.-H.; Ryu, S. Characterization of endolysin from a Salmonella Typhimurium-infecting bacteriophage SPN1S. Res. Microbiol. 2012, 163, 233-241. [CrossRef] [PubMed]

26. Pohane, A.A.; Joshi, H.; Jain, V. Molecular Dissection of Phage Endolysin an interdomain interaction confers host specificity in lysin a of mycobacterium phage D29. J. Biol. Chem. 2014, 289, 12085-12095. [CrossRef]

27. Oliveira, H.; Vilas Boas, D.; Mesnage, S.; Kluskens, L.D.; Lavigne, R.; Sillankorva, S.; Secundo, F.; Azeredo, J. Structural and enzymatic characterization of ABgp46, a novel phage endolysin with broad anti-Gram-negative bacterial activity. Front. Microbiol. 2016, 7, 208. [CrossRef]

28. Schmelcher, M.; Donovan, D.M.; Loessner, M.J. Bacteriophage endolysins as novel antimicrobials. Future Microbiol. 2012, 7, 1147-1171. [CrossRef]

29. Gerstmans, H.; Rodriguez-Rubio, L.; Lavigne, R.; Briers, Y. From endolysins to Artilysins ${ }^{\circledR}$ : Novel enzyme-based approaches to kill drug-resistant bacteria. Biochem. Soc. Trans. 2016, 44, 123-128. [CrossRef]

30. Ramasamy, K.P.; Telatin, A.; Mozzicafreddo, M.; Miceli, C.; Pucciarelli, S. Draft Genome Sequence of a New Pseudomonas sp. Strain, ef1, Associated with the Psychrophilic Antarctic Ciliate Euplotes focardii. Microbiol. Resour. Announc. 2019, 8, e00867-19. [CrossRef]

31. John, M.S.; Nagoth, J.A.; Ramasamy, K.P.; Mancini, A.; Giuli, G.; Natalello, A.; Ballarini, P.; Miceli, C.; Pucciarelli, S. Synthesis of Bioactive Silver Nanoparticles by a Pseudomonas Strain Associated with the Antarctic Psychrophilic Protozoon Euplotes focardii. Mar. Drugs 2020, 18, 38. [CrossRef] [PubMed]

32. Pucciarelli, S.; Devaraj, R.R.; Mancini, A.; Ballarini, P.; Castelli, M.; Schrallhammer, M.; Petroni, G.; Miceli, C. Microbial consortium associated with the Antarctic marine ciliate Euplotes focardii: An investigation from genomic sequences. Microb. Ecol. 2015, 70, 484-497. [CrossRef] [PubMed]

33. Kwon, S.W.; Kim, J.S.; Park, I.C.; Yoon, S.H.; Park, D.H.; Lim, C.K.; Go, S.J. Pseudomonas koreensis sp. nov., Pseudomonas umsongensis sp. nov. and Pseudomonas jinjuensis sp. nov., novel species from farm soils in Korea. Int. J. Syst. 2003, 53, 21-27. [CrossRef] [PubMed]

34. Arndt, D.; Grant, J.R.; Marcu, A.; Sajed, T.; Pon, A.; Liang, Y.; Wishart, D.S. PHASTER: A better, faster version of the PHAST phage search tool. Nucleic Acids Res. 2016, 44, W16-W21. [CrossRef] [PubMed]

35. Takenaka, S.; Ohnuma, T.; Fukamizo, T. Insertion of a Loop Structure into the "Loopless" GH19 Chitinase from Bryum coronatum. J. Appl. Glycosci. 2017, 64, 39-42. [CrossRef]

36. Boller, T.; Gehri, A.; Mauch, F.; Vögeli, U. Chitinase in bean leaves: Induction by ethylene, purification, properties, and possible function. Planta 1983, 157, 22-31. [CrossRef] [PubMed]

37. Levashov, P.A.; Sedov, S.A.; Shipovskov, S.; Belogurova, N.G.; Levashov, A.V. Quantitative turbidimetric assay of enzymatic gram-negative bacteria lysis. Anal. Chem. 2010, 82, 2161-2163. [CrossRef]

38. Banerjee, S.K.; Holler, E.; Hess, G.P.; Rupley, J.A. Reaction of N-acetylglucosamine oligosaccharides with lysozyme. Temperature, $\mathrm{pH}$, and solvent deuterium isotope effects; equilbrium, steady state, and pre-steady state measurements*. J. Biol. Chem. 1975, 250, 4355-4367.

39. Kelly, S.M.; Jess, T.J.; Price, N.C. How to study proteins by circular dichroism. Biochim. Biophys. Acta Proteins Proteom. 2005, 1751, 119-139. [CrossRef]

40. Buchholz, P.C.; Vogel, C.; Reusch, W.; Pohl, M.; Rother, D.; Spieß, A.C.; Pleiss, J. BioCatNet: A database system for the integration of enzyme sequences and biocatalytic experiments. ChemBioChem 2016, 17, 2093-2098. [CrossRef]

41. Davies, G.J.; Wilson, K.S.; Henrissat, B. Nomenclature for sugar-binding subsites in glycosyl hydrolases. Biochem. J. 1997, 321, 557. [CrossRef] [PubMed]

42. Choi, D.K. Evolution of the Taebaeksan Basin, Korea: I, early Paleozoic sedimentation in an epeiric sea and break-up of the Sino-Korean Craton from Gondwana. Isl. Arc 2019, 28, e12275. [CrossRef]

43. Barnes, D.K.; Clarke, A. Antarctic marine biology. Curr. Biol. 2011, 21, R451-R457. [CrossRef] [PubMed] 
44. Prakash, N.U.; Jayanthi, M.; Sabarinathan, R.; Kangueane, P.; Mathew, L.; Sekar, K. Evolution, homology conservation, and identification of unique sequence signatures in GH19 family chitinases. J. Mol. Evol. 2010, 70, 466-478. [CrossRef] [PubMed]

45. Åqvist, J.; Isaksen, G.V.; Brandsdal, B.O. Computation of enzyme cold adaptation. Nat. Rev. Chem. 2017, 1, 51. [CrossRef]

46. Briers, Y.; Lavigne, R. Breaking barriers: Expansion of the use of endolysins as novel antibacterials against Gram-negative bacteria. Future Microbiol. 2015, 10, 377-390. [CrossRef] [PubMed]

47. Park, Y.; Lim, J.A.; Kong, M.; Ryu, S.; Rhee, S. Structure of bacteriophage SPN 1 S endolysin reveals an unusual two-module fold for the peptidoglycan lytic and binding activity. Mol. Microbiol. 2014, 92, 316-325. [CrossRef] [PubMed]

48. Stern, A.; Sorek, R. The phage-host arms race: Shaping the evolution of microbes. Bioessays 2011, 33, 43-51. [CrossRef]

49. Seemann, T. Prokka: Rapid prokaryotic genome annotation. Bioinformatics 2014, 30, 2068-2069. [CrossRef]

50. Armenteros, J.J.A.; Tsirigos, K.D.; Sønderby, C.K.; Petersen, T.N.; Winther, O.; Brunak, S.; von Heijne, G.; Nielsen, H. SignalP 5.0 improves signal peptide predictions using deep neural networks. Nat. Biotechnol. 2019, 37, 420-423. [CrossRef]

51. Studier, F.W. Protein production by auto-induction in high-density shaking cultures. Protein Expr. Purif. 2005, 41, 207-234. [CrossRef]

52. Brocca, S.; Ferrari, C.; Barbiroli, A.; Pesce, A.; Lotti, M.; Nardini, M. A bacterial acyl aminoacyl peptidase couples flexibility and stability as a result of cold adaptation. FEBS J. 2016, 283, 4310-4324. [CrossRef] [PubMed]

53. Briers, Y.; Lavigne, R.; Volckaert, G.; Hertveldt, K. A standardized approach for accurate quantification of murein hydrolase activity in high-throughput assays. J. Biochem. Biophys. Meth. 2007, 70, 531-533. [CrossRef] [PubMed]

54. Katoh, K.; Standley, D.M. MAFFT multiple sequence alignment software version 7: Improvements in performance and usability. Mol. Biol. Evol. 2013, 30, 772-780. [CrossRef] [PubMed]

55. Gascuel, O. BIONJ: An improved version of the NJ algorithm based on a simple model of sequence data. Mol. Biol. Evol. 1997, 14, 685-695. [CrossRef] [PubMed]

56. Suchard, M.A.; Redelings, B.D. BAli-Phy: Simultaneous Bayesian inference of alignment and phylogeny. Bioinformatics 2006, 22, 2047-2048. [CrossRef] [PubMed]

57. Le, S.Q.; Gascuel, O. An improved general amino acid replacement matrix. Mol. Biol. Evol. 2008, 25, 1307-1320. [CrossRef] [PubMed]

58. Redelings, B.D.; Suchard, M.A. Incorporating indel information into phylogeny estimation for rapidly emerging pathogens. BMC Evol. Biol. 2007, 7, 40. [CrossRef]

59. Bansal, M.S.; Kellis, M.; Kordi, M.; Kundu, S. RANGER-DTL 2.0: Rigorous Reconstruction of Gene-Family Evolution by Duplication, Transfer, and Loss. Bioinformatics 2018, 34, 3214-3216. [CrossRef]

60. Fu, L.; Niu, B.; Zhu, Z.; Wu, S.; Li, W. CD-HIT: Accelerated for clustering the next-generation sequencing data. Bioinformatics 2012, 28, 3150-3152. [CrossRef]

61. Yang, J.; Zhang, Y. I-TASSER server: New development for protein structure and function predictions. Nucleic Acids Res. 2015, 43, W174-W181. [CrossRef] [PubMed]

62. Goddard, T.D.; Huang, C.C.; Meng, E.C.; Pettersen, E.F.; Couch, G.S.; Morris, J.H.; Ferrin, T.E. UCSF ChimeraX: Meeting modern challenges in visualization and analysis. Protein Sci. 2018, 27, 14-25. [CrossRef] [PubMed]

63. Dolinsky, T.J.; Czodrowski, P.; Li, H.; Nielsen, J.E.; Jensen, J.H.; Klebe, G.; Baker, N.A. PDB2PQR: Expanding and upgrading automated preparation of biomolecular structures for molecular simulations. Nucleic Acids Res. 2007, 35, W522-W525. [CrossRef] [PubMed]

64. Søndergaard, C.R.; Olsson, M.H.; Rostkowski, M.; Jensen, J.H. Improved treatment of ligands and coupling effects in empirical calculation and rationalization of $\mathrm{pK}_{\mathrm{a}}$ values. J. Chem. Theory Comput. 2011, 7, 2284-2295. [CrossRef] [PubMed]

65. Abraham, M.J.; Murtola, T.; Schulz, R.; Páll, S.; Smith, J.C.; Hess, B.; Lindahl, E. GROMACS: High performance molecular simulations through multi-level parallelism from laptops to supercomputers. SoftwareX 2015, 1, 19-25. [CrossRef] 
66. Lindahl, E.R. Molecular dynamics simulations. Methods Mol. Biol. 2008, 443, 3-23. [CrossRef]

67. Kuriata, A.; Iglesias, V.; Kurcinski, M.; Ventura, S.; Kmiecik, S. Aggrescan3D standalone package for structure-based prediction of protein aggregation properties. Bioinformatics 2019, 35, 3834-3835. [CrossRef]

Publisher's Note: MDPI stays neutral with regard to jurisdictional claims in published maps and institutional affiliations.

(C) 2020 by the authors. Licensee MDPI, Basel, Switzerland. This article is an open access article distributed under the terms and conditions of the Creative Commons Attribution (CC BY) license (http://creativecommons.org/licenses/by/4.0/). 